\title{
Homicidal Ideation
}

National Cancer Institute

\section{Source}

National Cancer Institute. Homicidal Ideation. NCI Thesaurus. Code C118205.

Thinking about ending or making plans to end another's life. 